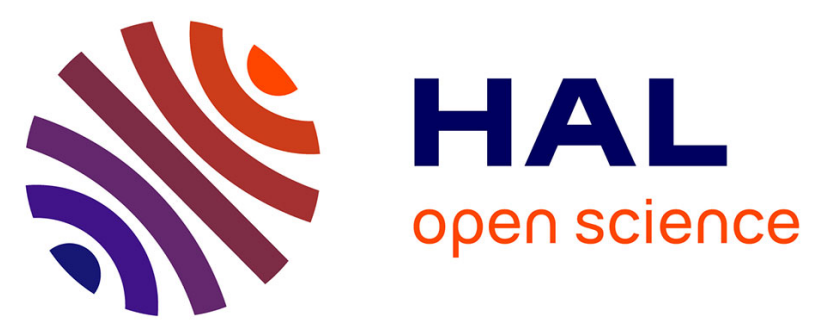

\title{
Chemical composition, antioxidant and antibacterial activities of Tamarix balansae J. Gay aerial parts
}

Abbes Benmerache, Mounira Benteldjoune, Abdulmagid Alabdul Magid, Amin Abedini, Djemaa Berrehal, Ahmed Kabouche, Sophie C. Gangloff, Laurence Voutquenne-Nazabadioko, Zahia Kabouche

\section{To cite this version:}

Abbes Benmerache, Mounira Benteldjoune, Abdulmagid Alabdul Magid, Amin Abedini, Djemaa Berrehal, et al.. Chemical composition, antioxidant and antibacterial activities of Tamarix balansae J. Gay aerial parts. Natural Product Research, 2017, 31 (24), pp.2828 - 2835. 10.1080/14786419.2017.1299729 . hal-01834098

\section{HAL Id: hal-01834098 \\ https://hal.univ-reims.fr/hal-01834098}

Submitted on 5 Nov 2021

HAL is a multi-disciplinary open access archive for the deposit and dissemination of scientific research documents, whether they are published or not. The documents may come from teaching and research institutions in France or abroad, or from public or private research centers.
L'archive ouverte pluridisciplinaire HAL, est destinée au dépôt et à la diffusion de documents scientifiques de niveau recherche, publiés ou non, émanant des établissements d'enseignement et de recherche français ou étrangers, des laboratoires publics ou privés. 


\title{
Chemical composition, antioxidant and antibacterial activities of aerial parts of Tamarix balansae $\mathbf{J}$. Gay aerial parts
}

Abbes Benmerache ${ }^{\mathrm{a}}$, Mounira Benteldjoune ${ }^{\mathrm{a}}$, Abdulmagid Alabdul Magid ${ }^{\mathrm{b}}$, Amin Abedini $^{\mathrm{b}, \mathrm{c}}$, Djemaa Berrehal ${ }^{\mathrm{a}}$, Ahmed Kabouche $^{\mathrm{a}}$, Sophie C. Gangloff ${ }^{\mathrm{c}}$, Laurence Voutquenne-Nazabadioko ${ }^{\mathrm{b}}$ and Zahia Kabouche ${ }^{\mathrm{a}, *}$

${ }^{a}$ Université des frères Mentouri-Constantine, Département de chimie, Laboratoire d'Obtention des Substances Thérapeutiques (LOST), Campus Chaabet-Ersas, 25000 Constantine, Algeria

bICMR-UMR CNRS 7312, Groupe Isolement et Structure, Campus Sciences, Bât. 18, BP 1039, 51687 Reims Cedex 2, France

'Laboratoire de Microbiologie, EA 4691, UFR de Pharmacie, 51 Rue Cognacq-Jay, 51100 Reims Cedex, France

* Corresponding author. Pr. Zahia Kabouche, Université des frères Mentouri-Constantine, Département de chimie, Laboratoire d'Obtention de Substances Thérapeutiques (L.O.S.T), 25000 Constantine, Algeria. E-mail : zahiakabouche@ gmail.com, Phone : (213)31811100

\begin{abstract}
A previously undescribed phenolic sulfate ester, potassium 3,4-dihydroxy-3-methoxybenzoic acid methyl ester-5-sulfate (1), along with nine known flavonoids, kaempferol-3-O-potassium sulfate-4',7-dimethyl ether (2), kaempferol-4',7-dimethyl ether (3), rhamnocitrin-3- $O$-potassium sulfate (4), rhamnocitrin (5), kaempferol (6), quercetin (7), afzelin (8), quercetin-3- $O-\alpha$-Lrhamnopyranoside (9) and luteolin-3'-O-potassium sulfate (10) were isolated from the aerial parts of Tamarix balansae. Structures elucidation was performed by comprehensive 1D and 2D NMR analyses, mass spectrometry and by comparison with literature data. The antibacterial assay against Enterococcus faecalis, Staphylococcus aureus, Staphylococcus epidermidis, Escherichia coli and Pseudomonas aeruginosa bacteria showed a good activity for 2, 3, 7 and $\mathbf{9}$, with MICs ranging from 62.5 to $250 \mu \mathrm{g} / \mathrm{mL}$. The abilities of these compounds to scavenge the DPPH were evaluated. Compounds 1, 7, 9 and $\mathbf{1 0}$ exhibited a good antiradical activity potential with $\mathrm{IC}_{50}$ values ranging from 3.0 to $115.5 \mu \mathrm{g} / \mathrm{mL}$, compared with ascorbic acid ( $\left.\mathrm{IC}_{50} 7.4 \mu \mathrm{g} / \mathrm{mL}\right)$ which was used as positive control.
\end{abstract}

Keywords: Tamarix balansae, Tamaricaceae, flavonoids, antibacterial activity, antioxidant activity

\section{Abbreviations:}

MH: Mueller-Hinton; MIC: Minimum Inhibitory Concentration; MTT: 3-(4,5-dimethylthiazol-2-yl)-2,5-diphenyltetrazolium) bromide; DPPH: 2,2-diphenyl-1-picrylhydrazyl.; DMSO: Dimethysulfoxide

\section{Introduction}

Tamaricaceae is a relatively small family containing four genera and about 125 species (Trease and Evans, 2002). Tamarix, represented by approximately 50 species, is the largest genus in this family. Tamarix plants are distributed from Morocco to India (Sultanova et al. 2001) with 10 species growing in Algeria (Quezel et Santa, 1963). Tamarix balansae J. Gay is an endemic Saharan plant growing in salty areas. Its leaves are long and wide, rarely slightly longer acute mucronate at the top, and the flower is colour pinkish-white to purple, small $(4-5 \mathrm{~mm})$, with capsules opening with 3 valves (4-5) $\mathrm{mm}$, the etamines (10) are inserted on the horns of the disc (Quezel et Santa, 1963). Tamarix species have been used in traditional medicine, especially as antiseptic agents and to treat leucoderma, spleen trouble and eye diseases (Nawwar et al., 1982). Polyphenolic compounds including, flavonoids (Lefahal et al. 2010, Mahfoudhia et al. 2014), phenolic acids (Akhlaq et al. 2012), tannins and lignans (Souliman et al 1991), represent the most common phytochemically investigated compounds in Tamarix species. Various species have been reported to possess antioxidant (Sultanova et al. 2001, Mohammedi et al. 2012), antimicrobial (Sultanova et al. 2001, Lefahal et al. 2010) or cytotoxic (Bakr et al. 2013) activities. Very recently, the aqueous extract of $T$. aphylla leaves has been used in an eco-friendly dyeing process of cotton modification (Baaka et al. 2017). The present study describes the isolation and the structure elucidation of a previously undescribed phenolic sulfate (1) and nine known flavonoids (2-10) from the aerial parts of Tamarix balansae. Their structural assignments were made by ESI-MS, 1D and 2D NMR analyses. As mentioned above, several Tamarix species have been reported to possess antioxidant and antibacterial activities, therefore DPPH radical scavenging inhibitory activity and antibacterial activity against Staphylococcus aureus, Enterococcus faecalis, Staphylococcus epidermidis, Pseudomonas aeruginosa and Escherichia coli of the constituents from the aerial parts of T. balansae were evaluated. 


\section{Results and discussion}

The $n-\mathrm{BuOH}$ soluble fraction of the $\mathrm{MeOH} 80 \%$ extract of dried aerial parts of $T$. balansae was fractionated and purified by combination of chromatographic methods to obtain a new phenolic sulfate (1) and nine known compounds (2-10). The known compounds were elucidated as kaempferol-3-O-potassium sulfate-4',7-dimethyl ether (2) (Nawwar et al. 1984), kaempferol-4',7-dimethyl ether (3) (Rossi et al. 1997), rhamnocitrin-3-O-potassium sulfate (4) (Fang et al. 2008), rhamnocitrin (5) (Mann et al. 1999), kaempferol (6) (Gangwal et al. 2010), quercetin (7) (Touafek et al. 2011), afzelin (8) (Granja-Pérez et al. 1999), quercetin-3-O- $\alpha$-L-rhamnopyranoside (9) (Zhang et al. 2014) and luteolin-3'-O-potassium sulfate (10) (Baron and Ibrahim, 1988) (Fig. 1).Their spectroscopic data were in perfect agreement with those reported in the literature.

Compound $\mathbf{1}$ was obtained as a white amorphous powder. The positive ESI-MS spectrum (Fig. S1) showed an $[\mathrm{M}+\mathrm{Na}]^{+}$ion at $\mathrm{m} / \mathrm{z} 339$, compatible with the molecular formula of $\mathrm{C}_{9} \mathrm{H}_{9} \mathrm{O}_{8} \mathrm{SK}$. The UV spectrum (Fig. S2) revealed an absorption band at $276 \mathrm{~nm}(\mathrm{MeOH})$. In the IR spectrum (Fig. S3), in addition to the obvious evidence for a hydroxyl (3324 $\left.\mathrm{cm}^{-1}\right)$, carbonyl $\left(1708 \mathrm{~cm}^{-1}\right)$ and aromatic ring (1606, $\left.1517 \mathrm{~cm}^{-1}\right)$, the strong absorption at 1232 and $1054 \mathrm{~cm}^{-1}$ was indicative of the presence of an $-\mathrm{O}^{-\mathrm{SO}_{3}}{ }^{-}$group (Barron et al., 1988). The presence of the sulfate group was confirmed

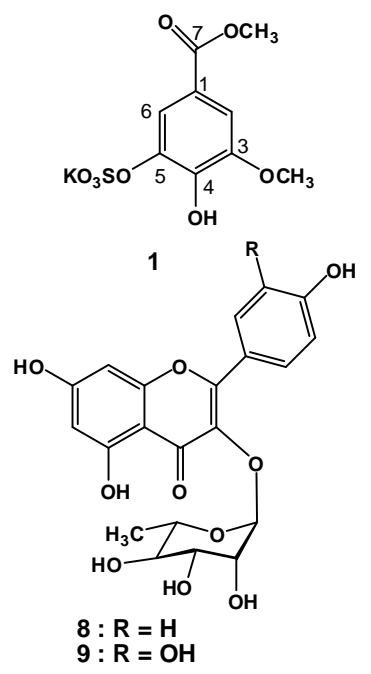

by precipitation with $\mathrm{BaCl}_{2}$, after acid hydrolysis of $\mathbf{1}$ (Xiao et al., 2002).

The ${ }^{1} \mathrm{H}$ and ${ }^{13} \mathrm{C}-\mathrm{NMR}$ spectra of compound $\mathbf{1}$ suggested a tetrasubstituted phenolic compound. Its aromatic ring was represented by signals for a pair of meta-coupled protons resonating at $\delta_{\mathrm{H}} 7.42$ and 7.76 (each $1 \mathrm{H}, \mathrm{d}, J=2.0 \mathrm{~Hz}$ ). In addition, characteristic signals for a carbonyl group $\left(\delta_{\mathrm{C}}\right.$ $168.2)$, a methoxy group $\left[\delta_{\mathrm{H}} 3.89(\mathrm{~s}, 3 \mathrm{H})\right.$ and $\left.\left.\delta_{\mathrm{C}} 56.7\right)\right]$, a methyl ester $\left[\delta_{\mathrm{H}} 3.86(\mathrm{~s}, 3 \mathrm{H})\right.$ and $\left.\left.\delta_{\mathrm{C}} 52.3\right)\right]$ and three signals of oxygenated aromatic carbons at $\delta_{\mathrm{C}} 141.5,145.4$ and 150.0 were observed (Table S1). Further interpretation of 2D NMR especially HMBC data established that compound $\mathbf{1}$ was a gallic acid derivative substituted by methoxy, methyl ester and sulfate groups (Xiao et al. 2002) (See supporting material, Fig. S8). The HMBC spectrum showed correlations between the methoxy group $\left(\delta_{\mathrm{H}} 3.89\right)$ and $\mathrm{C}-3$ $\left(\delta_{\mathrm{C}}\right.$ 150.0), which allowed the assignment of $\mathrm{OCH}_{3}$ in position $\mathrm{C}-3$ whereas correlations between the methyl ester group $\left(\delta_{\mathrm{H}} 3.86\right)$ and the carbonyl carbon placed the methyl ester group in position C-7 ( $\left.\delta_{\mathrm{C}} 168.2\right)$. Compound 1 was similar to gallic acid-3-methyl ether-5-sodium sulfate, previously isolated from Frankenia laevis L. (Hussein 2004). The only difference was in the presence of a methyl ester group in $\mathbf{1}$ and the nature of the sulfate moiety. Thus, compound 1 was identified to be potassium 3,4-dihydroxy3-methoxybenzoic acid methyl ester-5-sulfate.<smiles>O=c1c(P)c(-c2ccc(O)c(Br)c2)oc2cc(O)cc(O)c12</smiles>

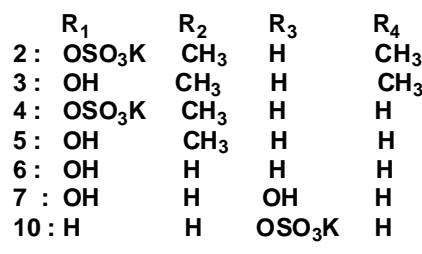

Figure 1: Chemical structures of compounds 1-10 isolated from T. balansae.

Table S1. NMR spectral data of compound 1 and gallic acid-3-methyl ether-5-sodium sulfate.

\begin{tabular}{llllll}
\hline & & & \\
& & & \\
\end{tabular}


The $n$-BuOH soluble fraction of $T$. balansae was initially tested for its antibacterial capacity against Staphylococus aureus CIP 53.154 by using TLC bioautography method (Benmerache et al., 2016).The results of agar-overlay bioautography revealed five inhibition zones on the developed extract. Each zone contains one or several antibacterial compounds. Subsequently, the $n$-BuOH soluble fraction was then fractionated and purified by combination of chromatographic methods to obtain ten compounds (1-10) and a second bioautography with compounds 1-10 was performed (Table S2). Compounds 2, 3, 7 and 9 showed a good antibacterial activity against $S$. aureus with 0.5 to 1.5 $\mathrm{cm}$ inhibition zone diameter.

A serial dilution technique using 96-well microtiter plates was used to determine the minimum inhibitory concentration values (MIC) of compounds 3, 7 and 9 against three Gram-positive (Enterococcus faecalis ATCC 1034, Staphylococcus aureus CIP 53.154 and Staphylococcus epidermidis) and two Gram-negative (Escherichia coli CIP 54.127 and Pseudomonas aeruginosa ATCC 9027) bacteria
(Table S2). These compounds showed a good antibacterial activity against the five bacteria. Compound $\mathbf{2}$ was the most active with MIC values of $62.5 \mu \mathrm{g} / \mathrm{mL}$ against E. faecalis, $S$. aureus, S. epidermidis and $P$. aeruginosa and $125 \mu \mathrm{g} / \mathrm{mL}$ against E. coli. Compound 9 also inhibited E. faecalis, $S$. epidermidis and P. aeruginosa (MIC $62.5 \mu \mathrm{g} / \mathrm{mL}$ ), S. aureus (MIC $125 \mu \mathrm{g} / \mathrm{mL}$ ) and E. coli (MIC $250 \mu \mathrm{g} / \mathrm{mL}$ ). Compound 3 showed a moderate antibacterial activity against the five tested bacteria with MIC values ranging from 125 to 250 $\mu \mathrm{g} / \mathrm{mL}$. The antibacterial potential of compound 7 was good against E. faecalis and $P$. aeruginosa (MIC $62.5 \mu \mathrm{g} / \mathrm{mL}$ ), moderate against $S$. epidermidis and S.aureus (MIC 125 $\mu \mathrm{g} / \mathrm{mL}$ ) and low against E. coli (MIC $500 \mu \mathrm{g} / \mathrm{mL}$ ). Comparison of the antibacterial activity of kaempferol-4',7dimethyl ether derivatives (2 and 3 ) suggested that potassium sulfate was favorable for the antibacterial activity in 2. In the same manner, comparison of the antibacterial activity of quercetin derivatives (7 and 9) suggested that the substitution by a rhamnopyranose residue (9) increases the antibacterial activity.

Table S2. Antibacterial activity of compounds 1-10 isolated from Tamarix balansae. ${ }^{\mathrm{a}}$

\begin{tabular}{|c|c|c|c|c|c|c|}
\hline & & & & $\mathrm{MIC}(\mu \mathrm{g} / \mathrm{mL})$ & & \\
\hline & $\begin{array}{c}\text { Bioautography against } \\
\text { S. aureus } \\
\text { CIP } 53.154\end{array}$ & $\begin{array}{c}\text { E. faecalis } \\
\text { ATCC } 1034\end{array}$ & $\begin{array}{c}\text { S. aureus } \\
\text { CIP 53.154 }\end{array}$ & S. epidermidis & $\begin{array}{c}\text { E. coli } \\
\text { CIP 54.127 }\end{array}$ & $\begin{array}{c}P . \text { aeruginosa } \\
\text { ATCC } 9027\end{array}$ \\
\hline 2 & ++ & 62.5 & 62.5 & 62.5 & 125 & 62.5 \\
\hline 3 & ++ & 125 & 250 & 250 & 250 & 250 \\
\hline 7 & +++ & 62.5 & 125 & 125 & 500 & 62.5 \\
\hline 9 & + & 62.5 & 125 & 62.5 & 250 & 62.5 \\
\hline Gentamicin $^{\text {b }}$ & ++ & $\mathrm{R}$ & $\mathrm{S}$ & $\mathrm{S}$ & $\mathrm{S}$ & $\mathrm{S}$ \\
\hline
\end{tabular}

${ }^{a}$ No activity was detected for compounds $\mathbf{1}, \mathbf{5 , 6 , 8}$ and $\mathbf{1 0}$ by bioautography

${ }^{\mathrm{b}}$ used as positive control

$(+)$ : significant effect, rated from $+(0.5 \mathrm{~cm}$ inhibition zone $)$ to $++++(>1.5 \mathrm{~cm}$ inhibition zone $)$; R: resistant; S: sensitive. MIC ( $\mu \mathrm{g} / \mathrm{mL})$ of positive control Gentamicin, $\mathrm{S}: \leq 4, \mathrm{R}:>8$.

The $n$-BuOH soluble fraction exhibited a mild DPPH radical scavenging activity $\left(\mathrm{IC}_{50} 48 \mu \mathrm{g} / \mathrm{mL}\right.$ ) compared to ascorbic acid, used as a positive control. The DPPH radical scavenging activity of compounds isolated from this fraction (1-10) was measured (Table S3). Compounds 7 and 9 possess an excellent antiradical activity $\left(\mathrm{IC}_{50} 3.01\right.$ and 13.6 $\mu \mathrm{g} / \mathrm{mL}$, respectively) comparable to ascorbic acid, used as a positive control ( $\mathrm{IC}_{50} 7.4 \mu \mathrm{g} / \mathrm{mL}$ ). Compounds $\mathbf{1}$ and $\mathbf{1 0}$ showed a low to moderate DPPH radical scavenging activity ( $\mathrm{IC}_{50} 115.5$ and $55.3 \mu \mathrm{g} / \mathrm{mL}$, respectively). The seven other compounds did not show scavenging activity at $200 \mu \mathrm{g} / \mathrm{mL}$.
Generally, substitution patterns of flavonoids on the B-ring especially affect antioxidant potencies of the flavonoids (Arora et al., 1998). Flavonols and flavones containing a catechol group in ring B are highly active, and flavonols are more potent than the corresponding flavones because of the presence of the 3-hydroxyl group (Pietta et al., 2000). These trends are consistent with the active compounds $\mathbf{7}$ and $\mathbf{9}$ possessing 3,3', $4^{\prime}-\mathrm{OH}$ pattern. Glycosylation of 3-hydroxyl group in compound $\mathbf{9}$ reduces the radical-scavenging capacity compared to compound 7. The lack of 3-hydroxyl group in compound $\mathbf{1 0}$ reduced the activity.

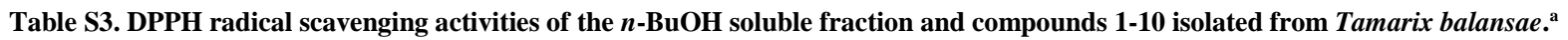

\begin{tabular}{lr}
\hline & IC $_{\mathbf{5 0}} \pm \mathbf{S . D .}(\boldsymbol{\mu g} / \mathbf{m L})$ \\
\hline $\boldsymbol{n}$-BuOH fraction & 48.0 \\
$\mathbf{1}$ & 115.5 \\
$\mathbf{7}$ & 3.01 \\
$\mathbf{9}$ & 13.6 \\
$\mathbf{1 0}$ & 55.3 \\
Ascorbic acid & \\
\hline
\end{tabular}

*50\% inhibition for compounds $\mathbf{2 - 6}$ and $\mathbf{8}$ not achieved at the concentration of $200 \mu \mathrm{g} / \mathrm{mL}$

${ }^{\mathrm{b}}$ used as positive control. 


\section{Experimental}

\subsection{General experimental procedures}

The optical rotations were recorded on a Perkin-Elmer 341 Polarimeter. The UV spectra were obtained in $\mathrm{MeOH}$ on a Shimadzu UV-2450 spectrophotometer. IR spectra were obtained using a Shimadzu IR-470 spectrometer. 1D and 2D NMR spectra were recorded in $\mathrm{CD}_{3} \mathrm{OD}$ on a Bruker Avance DRX III 500 spectrometer $\left({ }^{1} \mathrm{H}\right.$ at $500 \mathrm{MHz}$ and ${ }^{13} \mathrm{C}$ at 125 $\mathrm{MHz}$ ). ESI-MS experiments were performed using a Micromass Q-TOF instrument. Silica gel $60 \mathrm{~F}_{254}$ pre-coated aluminium plates $(0.2 \mathrm{~mm}$, Merck) were used for TLC analysis. The TLC and prepTLC spots were visualized under UV light (254 and $366 \mathrm{~nm}$ ) followed by spraying with $50 \%$ $\mathrm{H}_{2} \mathrm{SO}_{4}$ and heating. Column chromatography was carried out on Kieselgel 60 (63-200 mesh) Merck. Biological assays were read on a Fluostar Omega microplate reader (BMG labtech).

\subsection{Plant material}

Tamarix balansae J. Gay was collected from In Amenas (Illizi, South Eastern Algerian) in April 2013, during the flowering stage and authenticated by Mr. K. Kabouche. A voucher specimen has been deposited in the Herbarium of the laboratory of Therapeutic Substances (LOST), University frères Mentouri-Constantine (LOST Tb/04/13).

\subsection{Extraction and isolation}

The powdered dried aerial parts $(1.5 \mathrm{~kg})$ of Tamarix balansae were macerated at room temperature in $\mathrm{MeOH}$ $80 \%(3 \times 7 \mathrm{~L}, 24 \mathrm{~h})$. The extract was concentrated under low pressure, the residue (120 g) was dissolved with water (1L), and filtered, then successively extracted with dichloromethane and $n$ - $\mathrm{BuOH}(3 \times 300 \mathrm{~mL}$ each). After evaporation of the solvents, $1.5 \mathrm{~g}$ of $\mathrm{CH}_{2} \mathrm{Cl}_{2}$ and $16 \mathrm{~g}$ of $n$ $\mathrm{BuOH}$ extracts were obtained.

A part of $n-\mathrm{BuOH}$ extract (12 g) was subjected to column chromatography on polyamid SC6 $(90 \times 5.5 \mathrm{~cm})$, with a stepwise gradient of toluene-MeOH $(10: 0,0: 10)$ as eluent and 23 fractions of $250 \mathrm{~mL}$ were collected. Fraction 3 was purified by column chromatography on silica gel, eluted with $\mathrm{CHCl}_{3}$ to afford compound $2(10 \mathrm{mg})$. Fraction 6 was subjected to a silica gel column chromatography eluted with EtOAc:MeOH (9:1) leading to seven subfractions, the subfraction f3 was obtained as a yellow precipitate compound 3 (4 mg). Fraction 7 was purified by silica gel preparative TLC $(20 \times 20 \mathrm{~cm})$ with EtOAc-MeOH $(95: 5)$ as eluent to give compound 4 (5 mg). Fraction 9 was column chromatographed on silica gel, eluting with an isocratic system of EtOAc:MeOH (8:2) leading to nine subfractions, the subfraction $\mathrm{f} 4$ was separated by silica gel column chromatography eluted with an isocratic system of EtOAc:MeOH: $\mathrm{H}_{2} \mathrm{O}$ (20:2:1) affording compounds 5 (4 mg) and $6(8 \mathrm{mg})$. Fraction 14 was subjected to a silica gel column chromatography eluted with EtOAc:MeOH with increasing polarity leading to nine subfractions, the two subfractions $\mathrm{f} 7$ and $\mathrm{f} 9$ were purified by silica gel column eluted with an isocratic system of EtOAc:MeOH: $\mathrm{H}_{2} \mathrm{O}$
(20:2:1) affording compounds 7 (7 mg) and 8 (6 mg). Fraction 17 was subjected to a silica gel column chromatography eluted with EtOAc:MeOH with increasing polarity to give compounds $\mathbf{9}(4 \mathrm{mg})$ and $\mathbf{1 0}(5 \mathrm{mg})$. Fraction 21 containing one major spot was column chromatographed on silica gel eluting with an isocratic system of EtOAc: $\mathrm{MeOH}: \mathrm{H}_{2} \mathrm{O}(20: 2: 1)$ leading to five subfractions, the subfraction $\mathrm{f} 7$ was obtained as a white precipitate compound $1(18 \mathrm{mg})$.

\subsubsection{Potassium 3,4-dihydroxy-3-methoxybenzoic acid methyl ester-5-sulfate (1)}

Amorphous powder, $[\alpha]_{\mathrm{D}}{ }^{20}+187.5(c 0.3 \mathrm{MeOH})$. ESI-MS : $m / z 339.0[\mathrm{M}+\mathrm{Na}]^{+}$. UV $\lambda_{\max }(\mathrm{MeOH}, \mathrm{nm}): 276(\mathrm{sh}), \mathrm{IR}$ $(\mathrm{KBr}) \mathrm{cm}^{-1}$ : 3324, 1708, 1606, 1517, 1439, 1355, 1278, $1232,1201,1086,1054,1005 .{ }^{1} \mathrm{H}$ NMR $\left(500 \mathrm{MHz}, \mathrm{CD}_{3} \mathrm{OD}\right)$ : $\delta_{\mathrm{H}} 7.76(\mathrm{~d}, J=2.0 \mathrm{~Hz}, \mathrm{H}-6), 7.42(\mathrm{~d}, J=2.0 \mathrm{~Hz}, \mathrm{H}-2), 3.89$ $\left(\mathrm{s}, 3-\mathrm{OCH}_{3}\right), 3.86\left(\mathrm{~s}, 7-\mathrm{OCH}_{3}\right) \cdot{ }^{13} \mathrm{C}$ NMR (125 MHz, $\left.\mathrm{CD}_{3} \mathrm{OD}\right): \delta \mathrm{c} 168.2(\mathrm{C}-7), 150.0(\mathrm{C}-3), 145.4$ (C-5), 141.5 (C-4), 121.2 (C-1), 118.7 (C-6), 110.7 (C-2), 56.7 (3-OCH ${ }_{3}$, $52.3\left(7-\mathrm{OCH}_{3}\right)$.

\subsubsection{Acid Hydrolysis.}

Solutions of 1, 2, 4 and $\mathbf{1 0}$ (2 $\mathrm{mg}$ each) in $2 \mathrm{M} \mathrm{HCl}$ were heated at $100{ }^{\circ} \mathrm{C}$ for $1 \mathrm{~h}$. After cooling to room temperature, the hydrolysate was extracted with EtOAc. The recrystallized material was identified by its UV spectra in $\mathrm{MeOH}$ and by comparison of its $R f$ with authentic samples. $\mathrm{BaCl}_{2}$ was added to a sample of each aqueous layer, resulting in the formation of a white precipitate for compounds 1, 2, 4 and 10, confirming the presence of a sulfate moiety (Xiao et al., 2002).

\subsection{Antibacterial Activity}

Two methods were used to find and determinate this activity: bioautography and broth microdilution

\subsubsection{Evaluation of the antibacterial activity of compounds against $S$. aureus by bioautography}

At first to find out the antibacterial compounds, an immersion bioautography method was adopted (Abedini et al. 2013). An aliquot of each compound (2 $\mathrm{mg}$ ) was solubilized in $1 \mathrm{~mL}$ of $\mathrm{MeOH}$. The resulting solutions (25 $\mu \mathrm{L})$ were spotted onto Merck $60 \mathrm{~F}_{254}$ pre-coated silica gel plates $(10 \times 10 \mathrm{~cm})$. Gentamicin $(50 \mu \mathrm{g})$ was also spotted on the plates as a positive control. The TLC plates were directly dried without migration and sterilized. The plates were then covered by Mueller-Hinton (MH) agar medium containing a $S$. aureus suspension $\left(10^{5}\right.$ bacteria/mL) in square Petri dishes. After incubation $24 \mathrm{~h}$ at $37{ }^{\circ} \mathrm{C}$, bacterial growth was revealed by a $2 \mathrm{mg} / \mathrm{mL}$ solution of MTT and growth inhibition zones were measured. White stains indicate where reduction of MTT to the colored formazan did not take place due to the presence of compounds that inhibited bacterial growth. 


\subsubsection{MIC determination of the most active compound against five micro-organisms by broth microdilution}

A serial dilution technique using 96-well microliter plates was used to determine the MIC values of the most promising compounds as revealed by bioautography (Abedini et al. 2016). For this purpose, nine concentrations of the active compounds, from $500 \mu \mathrm{g} / \mathrm{mL}$ to $1.9 \mu \mathrm{g} / \mathrm{mL}$, were tested. Two wells were represented as bacteria culture control (positive control) and medium sterility control (negative control). Then the wells were loaded with $\mathrm{MH}$ liquid medium and bacterial suspension $\left(10^{5}\right.$ bacteria/mL) giving a final volume of $200 \mu \mathrm{L}$. The plates were incubated overnight at $37{ }^{\circ} \mathrm{C}$, sprayed with a $0.2 \mathrm{mg} / \mathrm{mL}$ MTT solution and incubated again at $37{ }^{\circ} \mathrm{C}$ for $30 \mathrm{~min}$. Bacterial growth was indicated by a violet color whatever the color intensity, while bacterial growth inhibition was admitted only for wells which remained clear. MIC values were determined as the lowest concentrations of samples having an inhibitory effect on bacteria growth (clear wells). This test was performed in triplicate.

\subsection{DPPH radical scavenging activity}

The scavenging activity of isolated compounds against DPPH was investigated by spectrophotometric methodology, as previously described (Benmerache et al., 2016). Briefly, $5 \mu \mathrm{L}$ of either standard or sample solutions (dissolved in DMSO) was mixed with $95 \mu \mathrm{L}$ of DPPH solution (158 $\mu \mathrm{M}$, dissolved in absolute EtOH). After mixing gently and incubating for $30 \mathrm{~min}$ at $37{ }^{\circ} \mathrm{C}$, the optical density was measured at $\lambda 515 \mathrm{~nm}$. The $\%$ scavenging activity was calculated using the following equation: \% inhibition $\left[\left(\mathrm{Ab}_{\text {control }}-\mathrm{Ab}_{\text {sample }}\right) / \mathrm{Ab}_{\text {control }}\right] \times 100$. DPPH solution in EtOH was used as a control. The curve of the $\%$ scavenging activity against the concentration of sample was prepared by the MS Excel based program to obtain the $\mathrm{IC}_{50}$. All the tests were conducted in triplicate. The experimental data were expressed as mean \pm standard deviation.

\section{Conclusions}

One new phenolic sulfate ester, along with nine known flavonoids, were isolated from the aerial parts of $T$. balansae. Compounds 2, 3, 7 and 9 showed antibacterial activity against E. faecalis, S. aureus, S. epidermidis, $P$. aeruginosa and $E$. coli with MICs ranging from 62.5 to 500 $\mu \mathrm{g} / \mathrm{mL}$. The DPPH radical scavenging activity assay showed a high activity for compound 7 compared with ascorbic acid used as a positive control. Compounds $\mathbf{1 , 9}$ and $\mathbf{1 0}$ exhibited a mild to low DPPH radical scavenging activity.

\section{Acknowledgements}

The authors are grateful to CNRS, Conseil Régional Champagne Ardenne, Conseil Général de la Marne and to the PlANET CPER project, for financial support. Algeria and French government for the Profas grant to Mr. Abbes Benmerache were also gratefully acknowledged. We also acknowledge Janick Madoux (Laboratory of Bacteriology, CHU Reims) for accessing to multiple inoculators material, and Chantal Grimplet for technical support.

\section{Supporting Information}

Antibacterial and DPPH radical scavenging activities of compounds 1-10 ESI-MS, IR, UV, and NMR data for compound 1

\section{References}

Abedini A, Chollet S, Angelis A, Borie N, Nuzillard JM, Skaltsounis AL, Reynaud R, Gangloff SC, Renault JH, Hubert J. 2016. Bioactivity-guided identification of antimicrobial metabolites in Alnus glutinosa bark and optimization of oregonin purification by Centrifugal Partition Chromatography. J Chromatogr B. 1029-1030: 121-127.

Abedini A, Roumy V, Mahieux S, Biabiany M, Standaert-Vitse A, Rivière C, Sahpaz S, Bailleul F, Neut C, Hennebelle T. 2013. Rosmarinic acid and its methyl ester as antimicrobial components of the hydromethanolic extract of Hyptisatrorubens Poit. (Lamiaceae), Evid. Based Compl. Alternat Med., 604536-604536.

Ahamado S, Rivière S, Neut C, Abedini A, Ranarivelo H, Duhal N, Roumy V, Hennebelle T, Sahpaz S, Lemoine A, Razafimahefa D, Razanamahefa, Bailleul F, Andriamihaja B. 2014. Antimicrobial prenylated benzoyl phloroglucinol derivatives and xanthones from the leaves of Garcinia goudotian. Phytochemistry. 102: 162-168.

Akhlaq M, Mouhamed A. 2011. New phenolic acids from the galls of Tamarix aphylla (L.) Karst. Int Res J Pharma. 2(4): 222-225.

Baaka N, Mahfoudhi A, Haddar W, Mhenni MF, Mighri Z. 2017. Green dyeing process of modified cotton fibres using natural dyes extracted from Tamarix aphylla (L.) Karst. leaves. Nat Prod Res. 31(1):22-31.

Bakr RO, El Raey MAE, Ashour RS. 2013. Phenolic content, radical scavenging activity and cytotoxicity of Tamarix nilotica (Ehrenb.) bunge growing in Egypt. J Pharmacognosy Phytoter. 5(3): 47-52.

Arora A, Nair MG, Strasburg GM. 1998. Structure-activity relationships for antioxidant activities of a series of flavonoids in a liposomal system. Free Radic. Biol. Med. 24(9): 13551363.

Barron D, Varin L, Ibrahim RK, Harborne JB, Williams CA. 1988. Sulfated flavonoids-an update. Phytochemistry. 27(8): 23752395.

Barron D, Ibrahim RK. 1988. Synthesis of flavonoid sulfates. II. The use of aryl sulfatase in the synthesis of flavonol-3-sulfates. Z. Naturforsch C. 43: 625-630.

Benmerache A, Alabdul Magid A, Berrehal D, Kabouche A, Voutquenne-Nazabadioko, L, Messaili S, Abedini A, Harakat D, Kabouche Z. 2016. Chemical composition, antibacterial, antioxidant and tyrosinase in hibitory activities of glycosides from aerial parts of Eryngium tricuspidatum L. Phytochem Lett. 18: 23-28. 
Fang S, Raob YK, Tzeng YM. 2008. Anti-oxidant and inflammatory mediator's growth inhibitory effects of compounds isolated from Phyllanthus urinaria. Phytochemistry. 116(2): 333-340.

Hussein SAM. 2004. Phenolic sodium sulfates of Frankenia laevis L. Pharmazie. 59(4): 304-308.

Gangwal A., Parmar SK, Sheth NR. 2010. Triterpenoid, flavonoids and sterols from Lagenaria siceraria fruits. Pharm Lett. 2(1): 307-317.

Granja-Pérez EP, Gamboa-Angulo MM, Escalante-Erosa F, PeñaRodríguez LM. 1999. Identification of kaempferol 3-O- $\square$-Lrhamnoside as a biotransformation product of Alternaria agetica. J Med. Chem Soc. 43: 188.

Lefahal M, Benahmed M, Louaar S, Zallagui A, Duddeck H, Medjroubi K, Akkal S. 2010. Antimicrobial activity of Tamarix gallica L. Extracts and isolated flavonoids. Adv Nat Sci. 4(3): 289-292.

Mahfoudhi A, Prencipe FP, Mighri Z, Pellati F, Mahfoudhi A, Prencipe FP, Mighri Z, Pellati F. 2014. Metabolite profiling of polyphenols in the Tunisian plant Tamarix aphylla (L.) Karst. J Pharm Biomed Anal. 99: 97-105.

Mann P, Tofern B, Kaloga M, Eich E. 1999. Flavonoid sulfates from the Convolvulaceae. Phytochemistry. 50(2): 267-271.

Mohammedi Z., Atik, F., 2012. HPLC-UV Analysis and antioxidant potential of phenolic compounds from endemic shrub of arid environment Tamarix pauciovulata J. Gay. J Life Sci. 6, 883-891.

Nawwar MAM, Buddrus J, Bauer H. 1982. Dimeric phenolic constituents from the roots of Tamarix nilotica. Phytochemistry. 21(7): 1755-1758.

Nawwar MAM, Souliman AMA, Buddrus J, Linscheid M. 1984. Flavonoids of the flowers of Tamarix nilotica. Phytochemistry. 23(10): 2347-2349.

Pietta PG. 2000. Flavonoids as antioxidants. J Nat Prod. 63(7): 1035-1042.

Quezel P, Santa S. 1963. New flora of Algeria and the southern desert regions. Paris. CNRS, 24.

Rossi MH, Yoshida M, Maia JGS. 1997. Neolignans, styrylpyrones and flavonoids from an Aniba species. Phytochemistry. 45(6): 1263-1269.

Souliman AMA, Baraka HT, EL-Mousallamy MAD, Marzouk MSA, Nawwar MAM. 1991. Phenolics from the bark of Tamarix aphylla. Phytochemistry. 30(11): 3763-3766.

Sultanova N, Makhmoor T, Abilov ZA, Parween Z, Omurkamzinova VB, Atta-ur-Rahman, Iqbal Choudhary M. 2001. Antioxidant and antimicrobial activities of Tamarix ramosissima. J Ethnopharmacol. 78(2-3): 201-205.

Touafek O, Kabouche Z, Brouard I, Bermejo JB. 2011. Flavonoids of Campanula alata and their antioxidant activity. Chem Nat Compd. 46(6): 968-970.

Trease GE, Evans WC. 2002. Pharmacognosy, WB Saunders Company Ltd, London, 15th ed., pp.30.

Xiao K, Xuan L, Xu Y, Bai D, Zhong D. 2002. Constituents from Polygonum cuspidatum. Chem. Pharm. Bull. 50(5): 605-608.

Zhang J, Chu CJ, Li XL, Yao S, Yan B, Ren, HL, Yu XN, Liang ZT, Zhao ZZ. 2014. Isolation and identification of antioxidant compounds in Vaccinium bracteatum Thunb. by UHPLC-QTOF LC/MS and their kidney damage protection. J Funct Foods. 11: 62-70. 